\title{
Ecological and behavioural variables affecting the fallow deer mating system in Doñana
}

\author{
C. SAN José and F. BrazA \\ Estación Biológica de Doñana (CSIC), Apdo. 1056, 41080 Sevilla, Spain
}

The rutting behaviour of fallow deer (Dama dama) at Doñana National Park (SW Spain) was studied in order to test the ecological and behavioural factors affecting variation in fallow deer mating strategies. Rutting area attendance was an important determinant of male reproductive success. An increase in population density during the study period did not seem to affect the variables related to the males' reproductive success, although a reduction in the size of area occupied by the males, and in the amount of their overlap between neighbours was detected. Despite this result, non-territorial strategies were perceived, and "dominance-groups" was the most successful mating strategy. In the past territorial strategies such as "rutting stands" have been described in the study area, but leks were never observed. It would appear, then, that in Doñana shifts in density do not fit the pattern which foresees that an increase in density contributes to continuous increases in territorial behaviour, reaching extremes such us multiple stands and lekking. Our study reveals that increases in density did not result in a change from non-territorial strategies. Our hypothesis is that when environmental conditions are unpredictable and/or the main mortality factors are predation and chaotic events, such as drought in the case of Doñana, environmental stress plays a more relevant role than social stress and density-dependent factors have a secondary influence on the variation in mating strategies.

KEY WORDS: Dama dama, Doñana, mating systems.

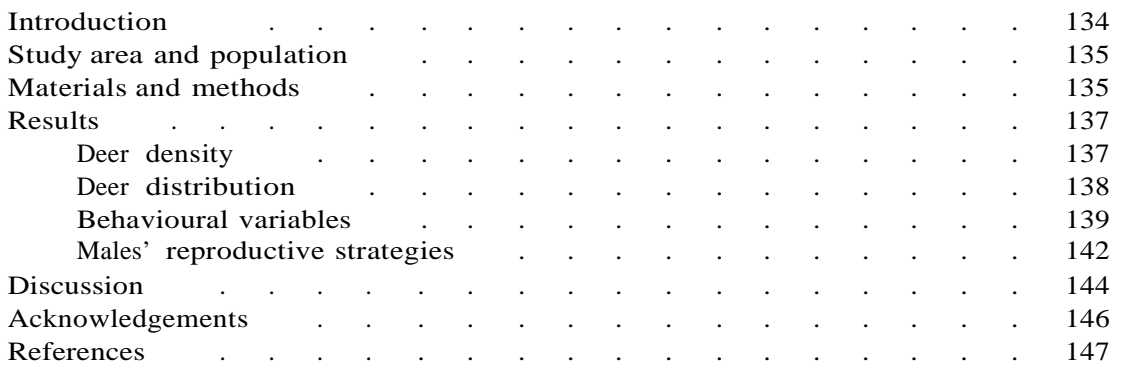




\section{INTRODUCTION}

Reproductive behaviour and mating strategies of fallow deer (Dama dama) vary from non-territorial to different levels of territorial behaviour (BRAzA et al. 1986; Schaal 1986, 1987; Clutton-Brock et al. 1988; Apollonio 1989; Langbein \& Thirgood 1989; Alvarez et al. 1990; Thirgood 1990; Moore et al. 1995). Many of these studies also reveal variation in behaviour between different individuals and within single individuals over time. The main explanation for variation in mating strategies of fallow deer is related to the energy costs of defending females and/or resources by males. All these mating strategies can be considered as a continuous gradient between two extremes: dominance-groups and leks (LANGBEIN \& THIRGOOD 1989).

Leks have never been observed in the Doñana fallow deer population, although stands, temporary stands, following, harem, and dominance-groups strategies (according to the classification of LANGBEIN \& THIRgOod 1989) have been described (Braza et al. 1986, Alvarez et al. 1990). We think that the question "why leks occur in some populations of fallow deer but not in others?" could be useful for defining the evolutionary process producing all mating strategies in this particular species.

Most evolutionary explanations of leks assume that females visit leks to choose between potential mating partners (Bradbury 1981, Queller 1987, Beehler \& FosTER 1988, ClutTON-Brock et al. 1993). Furthermore, lekking occurs in species where females typically live in large, unstable groups and where males cannot effectively defend female groups or resources where females congregate. In this case, the clustered territories of single males may also offer to females safety from harassment or predation (Clutton-Brock et al. 1993). Finally, lek-breeding seems to be related to high population densities (Apollonio 1989, LANGBEIN \& THIRgood 1989, Clutton-Brock et al. 1993).

In this study we shall analyse the fallow deer mating strategies observed in Doñana to elaborate a hypothesis of why some mating strategies but not others have been developed in this wild area.

In order to identify the mating strategies adopted by fallow deer males in Doñana, several variables already used by other authors (CLUTTON-BROCKet al. 1988, Apollonio 1989, Apollonio et al. 1989, Moore et al. 1995) have been selected: location, daily attendance and presence of males in the rutting areas, size of those areas, number of neighbours, and overlap rate of occupied areas between them, location and number of aggressive encounters, and fighting success.

To analyse the factors that contribute to the success of the different mating strategies adopted by individual males, we have selected the following parameters related to the reproductive success of males: number of females and number of copulations (see Clutton-Brock et al. 1988, Apollonio et al. 1989).

At the same time, we have considered other variables that might be expected to affect the territorial behaviour of males: sex ratio, male density, female density, habitat structure, and availability of resources (LANGBEIN \& THIRgOoD 1989).

With the results obtained we shall try to explain why lekking is not a successful strategy for fallow deer in Doñana, as well as to examine the advantages of the alternative strategies. 


\section{STUDY AREA AND POPULATION}

Doñana National Park, located on the southwestern coast of Spain, consists of 75,000 ha of protected area with a central Biological Reserve of 7,500 ha. The climate at Doñana is characterized by a low level of rainfall (ca $500 \mathrm{~mm}$ per annum), which normally begins in autumn, after a long dry summer (mean temperature of $24{ }^{\circ} \mathrm{C}$ in August).

In Doñana National Park, approximately $80 \%$ of the total fallow deer population concentrates in an ecotone area between marshes and shrub (BrAZA 1975, OJEDA et al. 1983, Braza et al. 1984, Braza \& AlVArEz 1987), characterized by meadows with rushes. This zone has well-defined limits and high productivity compared with the shrub and the dry marsh (Allier et al. 1974).

We selected as our study population the fallow deer living in a part of the ecotone zone of approximately $1 \times 6.5 \mathrm{~km}$ included in the Biological Reserve (BrAzA et al. 1990, SAN José \& BrAzA 1992a). The chosen study area and population can be considered as representative for the rest of the ecotone in the National Park (BRAzA et al. 1984). The study population has increased during the last 10 years from an average of 254 individuals in the 1980 s to 367 at the beginning of the 1990s (total counts by direct census; BrazA 1975, BrazA et al. 1986, SAN José \& BRAZA 1992a, present study). These numbers represent densities over 50 deer/100 ha which can be considered within the range of densities of population where lekking has been described (see revision in ApOLlONIO 1989).

The study of rutting behaviour was focused on the southernmost part of the ecotone area of the Biological Reserve, because there was a $30 \mathrm{~m}$ high tower from which it was possible to maintain permanent monitoring of the fallow deer. This "main study area" (approx. 80 ha) (Fig. 1) included one of the traditional rutting areas of the fallow deer in the Biological Reserve (BrazA et al. 1986, Alvarez et al. 1990).

In Doñana the rutting season for fallow deer occurs during the first half of October (BRAzA et al. 1986) and their main reproductive period can be considered strongly synchronized compared with other fallow deer populations: in Doñana $70 \%$ of births occur in a period of 6 days (BRAzA et al. 1988, SAN José \& BRAZA 1992b) whereas in other populations there is evidence of a winter reproductive phase as well as the presence of late births (STÈRBA \& KLUSÁK 1984; SCHAAL 1985a, 1985b, 1987). Without a doubt, this synchrony has its origin in ancestral conditions of the Mediterranean populations, which in Doñana was subjected to predation by wolves until 1947 (CAstroviejo 1993) and nowadays by the lynx (Beltran et al. 1986).

\section{MATERIALS AND METHODS}

In order to ascertain population size as well as social structure during the rutting season, periodic counts were conducted in this study area from the end of September to the middle of October in 1990 and in 1991. The observers followed a standard route along the 6.5 $\mathrm{km}$ of the ecotone area by car during the early morning hours (06:00-07:00 hr). The open characteristics of that area allowed two observers (apart from the driver) to record the number and group composition of all fallow deer present. The following sex and age classes were considered: adult males older than 4 years, subadult males 2-3 years old, and females older than 1 year (for more details of census method see BrAzA et al. 1986, 1990).

In order to obtain information about the botanical composition of the "main study area”, we selected 15 plots (of about $5 \mathrm{~m}^{2}$ ) for analysis. Cluster analysis was applied to the coefficients of similarity between the different plots (with 42 plant species considered), using Jacquard's formula (LudWING \& REYNOLDS 1988).

For recording data related to rutting behaviour, a team of 2-3 observers positioned in the tower kept a continuous daytime watch (using a telescope) on the "main study area" from the 28th-30th September to the 15th October in 1990 and 1991. 


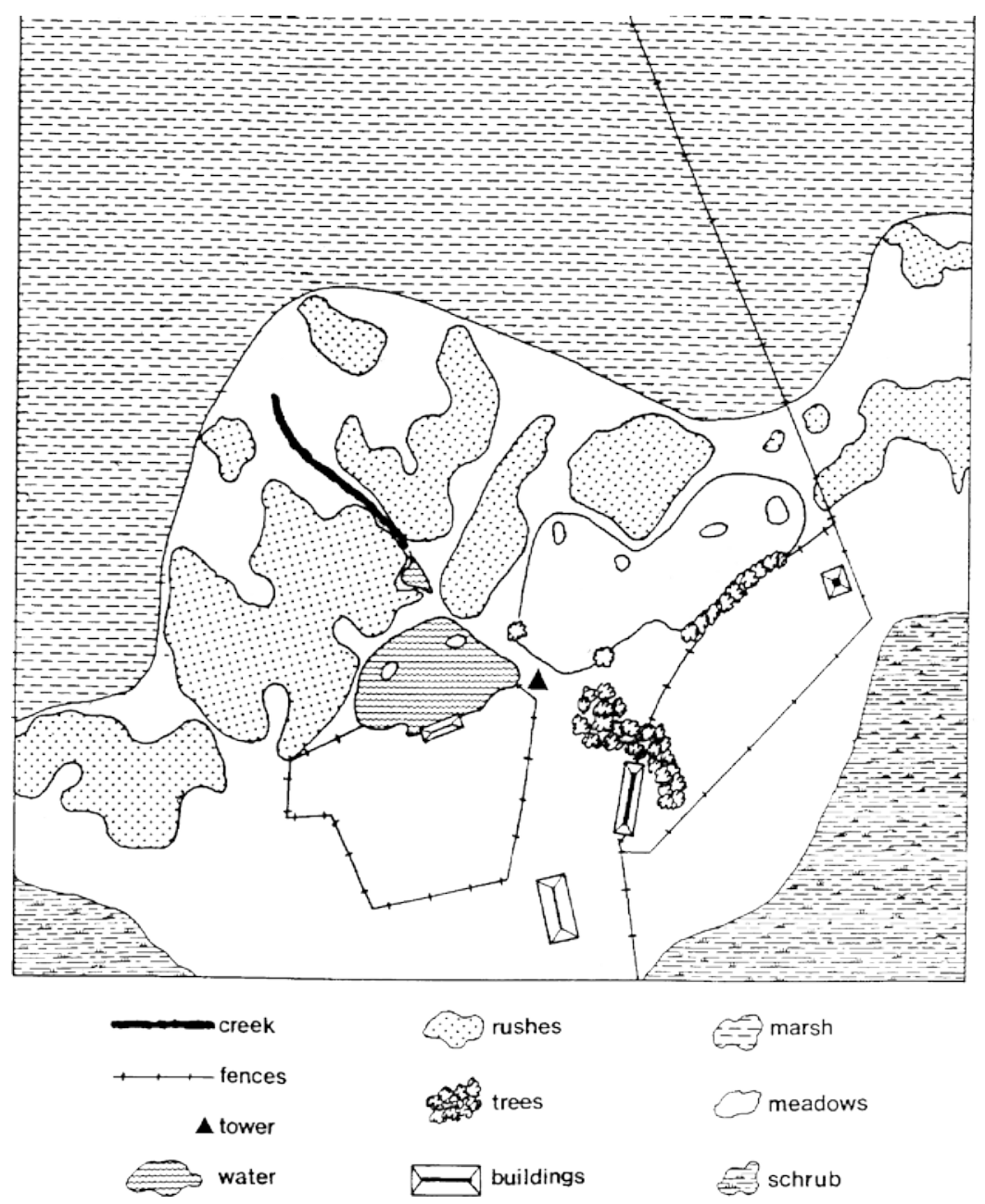

Fig. 1. - Main study area.

The position of all deer present at 06:30 hr and 17:00 hr was plotted on a grid map of the area (74 squares of approx. 1 ha). Using natural markings, especially the shape of the antlers, all the individual males inhabiting the "main study area" could be recognized. The positions of all adult males present in the area were plotted on average 8 times per day, at intervals of 1 hr. Eighty-seven maps in 1990 and 61 maps in 1991 were used for individual analysis. The analysis was undertaken for those males that occurred in at least $50 \%$ of the maps (referred to as sedentary males: 10 males in 1990 and 11 males in 1991).

For description of the males' mating strategies we followed the classification proposed by LANGBein \& THIRgOoD (1989): (a) territorial strategies (where mature bucks defend exclusive reproductive territories), including stand, temporary stand, multiple stand and lek, (b) non-territorial strategies (where no territorial behaviour is exhibited by bucks), including following, harem and dominance-groups. To identify the different mating strategies the following variables were analysed. 
A value of presence/day for each sedentary buck was calculated as the mean percentage of maps/day in which the buck was sighted within the area.

An index of presence (PR) during the rutting season weighted the average presence/day with the percentage of days of the rutting period in which each male occupied the study area.

$$
\mathrm{PR}=\frac{\text { mean presence } / \text { day } \times \% \text { of days in the area }}{100}
$$

The limits of the males' rutting areas were defined by connecting the outer locations (Convex Polygon; Kenward 1987). The size of rutting areas was estimated using the Modified Minimum Area Method (Harvey \& Barbour 1965): for each buck we used only points located less than a $1 / 4$ of the distance between the two points of location that were farthest apart. A computer program (MACDRAFT 1.2a) was used to measure the area.

In addition, the number of neighbours and the overlap rate with neighbouring rutting areas were estimated for each male. Location and the mean number of aggressive encounters per day as well as the total number of fights and aggressive encounters without fights (no physical contact) were also calculated for each male.

Using those fights that had a clear outcome, we calculated the fighting success (FS) for each buck following the method of CLUTTON-Brock et al. (1979, 1988):

$$
\mathrm{FS}=\frac{\mathrm{B}+\mathrm{b}+1}{\mathrm{~L}+\mathrm{k}+1}
$$

where $B$ was the number of different bucks the individual was seen to beat, $b$ the total of individuals that they were seen to beat, $L$ the number of different bucks that the individual was seen to lose to, and $k$ the total of individuals that beat them.

Because the number of copulations seen was low, harem size for each male was also calculated. Taking into account that LANGBEIN \& THIRGOOD (1989) defined harem as a group of females held by a single mature male for the purpose of obtaining exclusive mating rights, we have considered of harems those groups made up of one or more adult females accompanied by only one adult male or by one adult male with younger males. According to other authors (Clutton-Brocket al. 1988, Apollonio et al. 1989), harems size in fallow deer is highly correlated with the reproductive success of males.

Every day during the whole study period, the frequency of groaning per minute in the main area was also recorded for $10 \mathrm{~min}$, from $5 \mathrm{~min}$ before to $5 \mathrm{~min}$ after sunrise.

ANOVA was used to analyse differences between years. The percentage data were arcsine transformed. Pearson's correlations were established between the different variables considered in each year (SIEGEL 1956). The program NTSYS 1.50 (SNELL 1987) was used for cluster analysis. Chi-squared test was used to analyse differences in deer distribution between years and sexes.

\section{RESULTS}

From the groan activity pattern (Fig. 2), we considered the main period of males' rutting activity to be from the 2nd to the 12th October inclusive in 1990 and from the 2nd to the 9th October in 1991.

\section{Deer density}

The size of the fallow deer population living in the ecotone area of the Biological Reserve increased from 343 ( \pm 31.8) individuals in 1990 to 390.5 ( \pm 28.8) individuals in 1991 (ANOVA $F=5.16, P=0.057$ ), with a significant increase in the 


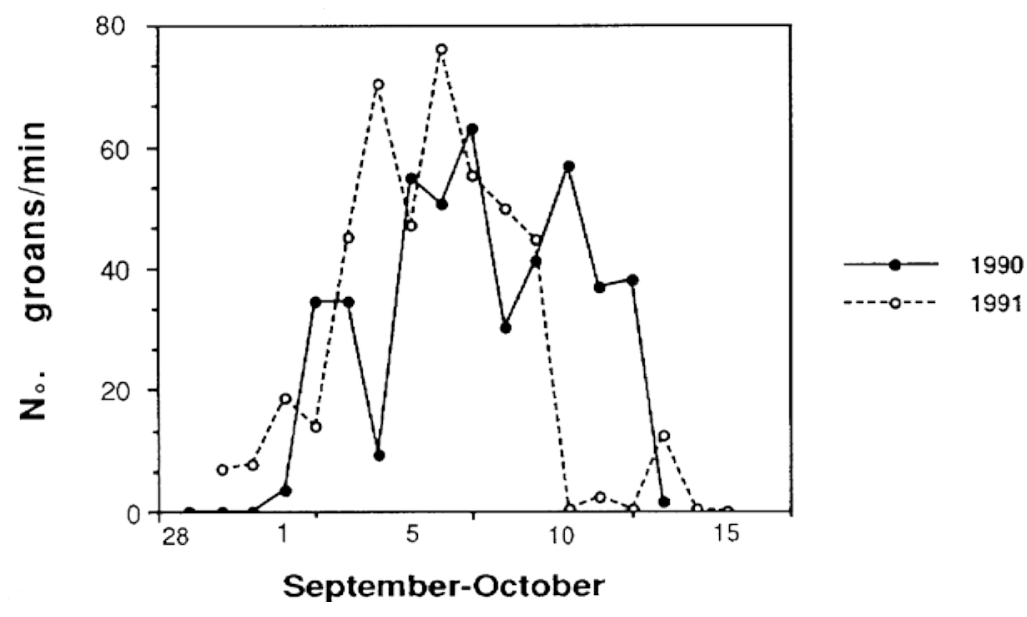

Fig. 2. - Frequency of groaning per minute.

“main study area”, from $61.39( \pm 5.9)$ to 75.33 ( \pm 9.0) individuals (ANOVA F = 24.87, $P=0.0001$ ). This implies an increase in density from 76 deer/100 ha in 1990 to 94 deer/100 ha in 1991 . That tendency was similar when considering the number of males and females, without any significant change in the operational sex ratio (females/adult male) (Table 1).

\section{Deer distribution}

The analysis of the deer distribution pattern in the 74 one ha-squares of the "main study area" revealed a selective use of that area $\left(X^{2}=928.131\right.$, $\mathrm{df}=73 ; P<$ 0.00001 for 1990 , and $X^{2}=903.128$, $\mathrm{df}=73 ; P=0.00001$ for 1991) (Fig. 3). After

Table 1.

Numbers of males and females in the study area.

\begin{tabular}{|c|c|c|c|c|c|c|}
\hline Area & Year & $\begin{array}{c}\text { No } \\
\text { census }\end{array}$ & Females & $\begin{array}{l}\text { Adult } \\
\text { males }\end{array}$ & $\begin{array}{l}\text { Subadult } \\
\text { males }\end{array}$ & $\begin{array}{l}\text { Operational } \\
\text { sex ratio }\end{array}$ \\
\hline \multirow{3}{*}{$\begin{array}{l}\text { Biological } \\
\text { reserve }\end{array}$} & 1990 & 3 & $154.7 \pm 18.1$ & $60.7 \pm 2.0$ & $43.3 \pm 13.6$ & $2.6 \pm 0.3$ \\
\hline & 1991 & 6 & $180.3 \pm 20.0$ & $63.2 \pm 6.9$ & $27.5 \pm 6.2$ & $3.0 \pm 0.6$ \\
\hline & \multicolumn{2}{|l|}{ ANOVA } & NS & NS & NS & NS \\
\hline \multirow{3}{*}{$\begin{array}{l}\text { Main study } \\
\text { area }\end{array}$} & 1990 & 14 & $27.5 \pm 2.9$ & $8.8 \pm 1.7$ & $8.8 \pm 1.9$ & $3.2 \pm 0.6$ \\
\hline & 1991 & 18 & $34.6 \pm 5.2$ & $11.5 \pm 3.4$ & $5.4 \pm 1.8$ & $3.5 \pm 1.8$ \\
\hline & \multicolumn{2}{|l|}{ ANOVA } & $\begin{array}{c}\mathrm{F}=21.32 \\
P=0.0001\end{array}$ & $\begin{array}{c}\mathrm{F}=7.4 \\
P=0.0108\end{array}$ & NS & NS \\
\hline
\end{tabular}



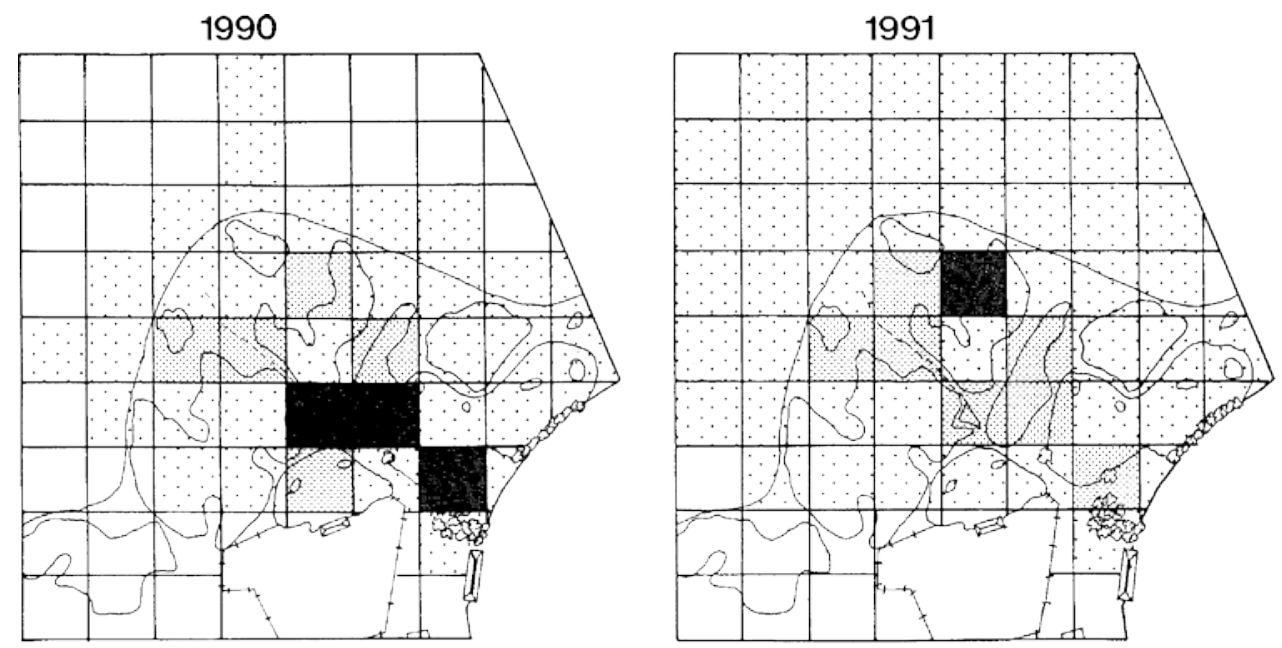

No. DEER/DAY

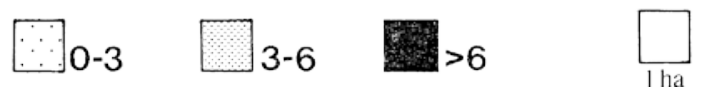

Fig. 3. - Distribution pattern of deer in the main study area.

studying the botanical composition in the "main study area" (Fig. 1) it was possible to distinguish two dominant zones: the meadows with rushes (mainly Juncus spp., Cyperus spp., Cynodon sp.) and a transitional area between meadows and marsh (Scirpus maritimus, Eleocharis multicaulis, Cynodon sp.). The meadows close to a creek were the most used in both years. In 1990 the preferred squares were concentrated at the source of the creek, whereas in 1991 they were in the rush meadows between the creek and marshland. In any case, the distribution of males and females followed the same pattern in 1990 and $1991\left(X^{2}=21.21\right.$, $\mathrm{df}=16$; $\mathrm{NS}$ and $\mathrm{X}^{2}=$ 38.207, $\mathrm{df}=32$; NS, respectively; the squares with the expected small values were grouped with the neighbouring ones).

There was a slight change in deer distribution between 1990 and $1991\left(X^{2}=\right.$ 32.215, df $=17 ; P<0.025$. A tendency to move in a North-Eastern direction from 1990 to 1991 was detected (North-South: $\mathrm{F}=44.06, P=0.00001$; East-West: $\mathrm{F}=$ 146.45, $P=0.00001$; ANOVA).

\section{Behavioural variables}

The mean presence/day and the index of presence were positively correlated in both years with fighting success and the number of copulations (Tables 2 and 3). Furthermore, in 1991 the index of presence showed a positive correlation with the number of aggressive encounters per day (Table 3).

The average size of the area occupied by individual males in 1990 was significantly larger than in 1991 ( $F=7.81, P=0.0116$; ANOVA). Likewise, the average 
Table 2.

Some observed features of the sedentary males in 1990 and 1991.

\begin{tabular}{|c|c|c|c|c|c|c|c|c|c|c|c|}
\hline Males & $\begin{array}{l}\text { Presence/ } \\
\text { day }\end{array}$ & $\begin{array}{c}\text { Index } \\
\text { presence }\end{array}$ & $\begin{array}{l}\text { Area } \\
\text { (ha) }\end{array}$ & $\begin{array}{c}\text { No. } \\
\text { neighbours }\end{array}$ & $\begin{array}{c}\% \\
\text { overlap }\end{array}$ & $\begin{array}{l}\text { Aggressive } \\
\text { encounters }\end{array}$ & $\begin{array}{l}\text { No. of } \\
\text { fights }\end{array}$ & $\begin{array}{c}\text { No. aggressive } \\
\text { encounters } \\
\text { (without fights) }\end{array}$ & $\begin{array}{l}\text { Fighting } \\
\text { success }\end{array}$ & $\begin{array}{c}\text { No. } \\
\text { females }\end{array}$ & Copulations \\
\hline $\mathrm{Ra}$ & $93.6 \pm 7.9$ & 93.6 & 10.5 & 9 & 100.0 & 1.6 & 7 & 10 & 9.0 & $2.4 \pm 1.8$ & 8 \\
\hline To & $77.2 \pm 20.2$ & 77.2 & 11.5 & 9 & 86.5 & 2.5 & 12 & 8 & 2.6 & $6.2 \pm 5.5$ & 4 \\
\hline $\mathrm{Bi}$ & $78.1 \pm 22.4$ & 56.8 & 14.1 & 9 & 100.0 & 0.6 & 1 & 6 & 3.3 & $2.1 \pm 1.8$ & 2 \\
\hline Ro & $83.8 \pm 29.2$ & 68.6 & 13.6 & 9 & 97.6 & 1.1 & 3 & 5 & 1.1 & $2.1 \pm 2.1$ & 0 \\
\hline $\mathrm{He}$ & $66.3 \pm 22.5$ & 60.2 & 11.3 & 9 & 90.3 & 1.0 & 5 & 9 & 0.3 & $2.2 \pm 1.2$ & 0 \\
\hline $\mathrm{Ab}$ & $68.7 \pm 38.4$ & 43.7 & 8.4 & 9 & 100.0 & 1.2 & 6 & 8 & 1.4 & $2.1 \pm 1.9$ & 0 \\
\hline $\mathrm{Di}$ & $67.2 \pm 14.2$ & 61.1 & 9.0 & 9 & 100.0 & 0.2 & 0 & 2 & 0.2 & $2.8 \pm 1.7$ & 0 \\
\hline $\mathrm{Pu}$ & $67.1 \pm 16.8$ & 54.9 & 4.8 & 9 & 100.0 & 0.2 & 2 & 1 & 1.7 & $1.3 \pm 0.6$ & 0 \\
\hline $\mathrm{Si}$ & $67.6 \pm 24.5$ & 55.3 & 8.6 & 9 & 100.0 & 0.8 & 7 & 3 & 0.4 & $1.0 \pm 0.0$ & 0 \\
\hline $\mathrm{Mi}$ & $56.7 \pm 19.8$ & 36.1 & 9.4 & 9 & 100.0 & 0.3 & 0 & 3 & 0.2 & $1.3 \pm 0.6$ & 0 \\
\hline $\bar{x}$ & 72.6 & 60.7 & 10.1 & 9 & 97.4 & 0.9 & 4.3 & 5.5 & 2.0 & 2.3 & 1.4 \\
\hline SD & 10.6 & 16.3 & 2.7 & 0 & 4.5 & 0.7 & 3.8 & 3.0 & 2.7 & 1.5 & 2.7 \\
\hline Oj & $98.6 \pm 3.9$ & 98.6 & 9.3 & 10 & 100.0 & 1.9 & 2 & 20 & 31.0 & $3.8 \pm 3.9$ & 4 \\
\hline Bo & $59.8 \pm 32.5$ & 59.7 & 4.2 & 5 & 64.8 & 0.9 & 3 & 6 & 2.7 & $4.8 \pm 4.1$ & 0 \\
\hline $\mathrm{Pa}$ & $67.7 \pm 29.6$ & 67.7 & 8.4 & 9 & 83.8 & 1.2 & 5 & 8 & 1.2 & $2.2 \pm 1.2$ & 0 \\
\hline Go & $86.0 \pm 12.9$ & 53.7 & 7.6 & 7 & 85.0 & 0.8 & 4 & 4 & 0.9 & $1.8 \pm 0.3$ & 2 \\
\hline $\mathrm{Ca}$ & $71.8 \pm 13.8$ & 71.8 & 10.6 & 9 & 86.6 & 1.5 & 12 & 7 & 1.3 & $1.7 \pm 0.8$ & 1 \\
\hline $\mathrm{Qu}$ & $62.1 \pm 19.3$ & 54.3 & 4.4 & 7 & 79.0 & 0.5 & 2 & 4 & 0.3 & $3.7 \pm 2.5$ & 0 \\
\hline $\mathrm{Fe}$ & $49.0 \pm 14.2$ & 49.0 & 4.5 & 5 & 100.0 & 0.4 & 0 & 4 & 0.5 & $3.5 \pm 0.7$ & 0 \\
\hline $\mathrm{Ba}$ & $57.1 \pm 27.0$ & 50.0 & 7.1 & 10 & 100.0 & 0.3 & 2 & 1 & 0.5 & $2.2 \pm 1.6$ & 0 \\
\hline Sp & $59.9 \pm 21.4$ & 37.4 & 6.9 & 7 & 73.5 & 0.5 & 2 & 3 & 0.1 & $1.2 \pm 0.4$ & 0 \\
\hline $\mathrm{Nu}$ & $60.9 \pm 23.8$ & 60.8 & 8.4 & 7 & 69.8 & 1.9 & 8 & 11 & 1.7 & $1.5 \pm 0.5$ & 0 \\
\hline $\mathrm{Li}$ & $66.8 \pm 28.8$ & 66.8 & 7.6 & 10 & 100.0 & 1.9 & 6 & 13 & 0.8 & $1.7 \pm 1.7$ & 0 \\
\hline $\bar{x}$ & 67.2 & 60.9 & 7.2 & 7.8 & 85.7 & 1.1 & 4.2 & 7.4 & 3.7 & 2.6 & 0.6 \\
\hline SD & 14.0 & 15.9 & 2.1 & 1.9 & 13.1 & 0.6 & 3.4 & 5.5 & 9.1 & 1.2 & 1.3 \\
\hline
\end{tabular}


overlap in these areas showed a significant decrease from 1990 to 1991 ( $\mathrm{F}=5.9, P$ $=0.0252$; ANOVA). There were no significant differences between years in any of the other variables (Table 2).

In 1990 the percentage of overlap was positively correlated with two other variables: number of females and number of aggressive encounters/day. In 1991 those correlations were not detected, but the larger areas corresponded to both a higher number of neighbours and a higher number of aggressive encounters per day.

In 1990 (but not in 1991) the number of aggressive encounters per day was positively correlated with the number of females (harems size). Finally, fighting success and copulations were correlated in both years (Table 3 ).

Table 3.

Correlations between different variables considered in 1990 and 1991 .

\begin{tabular}{|c|c|c|c|c|c|c|}
\hline & $\begin{array}{l}\text { Number of } \\
\text { neighbours }\end{array}$ & $\begin{array}{l}\text { Number of } \\
\text { females }\end{array}$ & $\begin{array}{r}\text { Agg } \\
\text { encou }\end{array}$ & $\begin{array}{l}\text { gressive } \\
\text { nters/day }\end{array}$ & $\begin{array}{l}\text { Fighting } \\
\text { success }\end{array}$ & Copulations \\
\hline \multirow{3}{*}{$\begin{array}{l}\text { Index } \\
\text { presence }\end{array}$} & - & - & & - & $\mathrm{r}=0.75$ & $r=0.82$ \\
\hline & - & - & & - & $F=10.15$ & $F=16.12$ \\
\hline & - & - & & - & $P=0.0120$ & $P=0.0039$ \\
\hline \multirow{3}{*}{ Presence/day } & - & - & & - & $\mathrm{r}=0.82$ & $r=0.77$ \\
\hline & - & - & & - & $F=15.95$ & $F=11.83$ \\
\hline & - & - & & - & $P=0.0040$ & $P=0.0088$ \\
\hline \multirow[t]{3}{*}{$\%$ overlap } & - & $\mathrm{r}=0.77$ & $r=$ & 0.69 & - & - \\
\hline & - & $F=12.16$ & $\mathrm{~F}=$ & 7.24 & - & - \\
\hline & - & $P=0.0082$ & $P=$ & 0.0270 & - & - \\
\hline \multirow{3}{*}{$\begin{array}{l}\text { Aggressive } \\
\text { encounters/day }\end{array}$} & - & 0.78 & & - & - & - \\
\hline & - & $F=22.58$ & & - & - & - \\
\hline & - & $P=0.0010$ & & - & - & - \\
\hline \multirow[t]{3}{*}{ Fighting success } & - & - & & - & - & $r=0.94$ \\
\hline & - & - & & - & - & $F=65.56$ \\
\hline & - & - & & - & - & $P=0.0001$ \\
\hline \multirow{3}{*}{$\begin{array}{l}\text { Index } \\
\text { presence }\end{array}$} & - & - & $r=$ & 0.76 & $r=0.81$ & $r=0.72$ \\
\hline & - & - & $\mathrm{F}=$ & 12.53 & $F=17.27$ & $F=9.70$ \\
\hline & - & - & $P=$ & 0.0063 & $P=0.0025$ & $P=0.0120$ \\
\hline \multirow{3}{*}{ Presence/day } & - & - & & - & $\mathrm{r}=0.74$ & $r=0.93$ \\
\hline & - & - & & - & $F=11.18$ & $F=55.97$ \\
\hline & - & - & & - & $P=0.0086$ & $P=0.0001$ \\
\hline \multirow[t]{3}{*}{ Area (ha) } & $r=0.71$ & - & $r=$ & 0.66 & - & - \\
\hline & $F=9.21$ & - & $\mathrm{F}=$ & 6.90 & - & - \\
\hline & $P=0.0140$ & - & $P=$ & 0.0270 & - & - \\
\hline \multirow[t]{3}{*}{ Fighting success } & - & - & & - & - & $\mathrm{r}=0.87$ \\
\hline & - & - & & - & - & $F=26.83$ \\
\hline & - & - & & - & - & $P=0.0006$ \\
\hline
\end{tabular}


Males' reproductive strategies

As can be seen in Table 2 and Figs 4 and 5, two males $(<\mathrm{Ra}>$ in 1990 , and $\langle\mathrm{Oj}\rangle$ in 1991), whose rutting areas were located around the creek, followed a dominance-groups mating strategy (LANGBEIN \& THIRGOOD 1989). Both males shared their rutting areas with other adult males (multimale-mixed sex groups) being dominant over them (through a high fighting success) and achieved most matings (number of copulations). It is interesting to note that these males had a high number of aggressive encounters but with relatively few fights (Table 2). In both years fighting success was positively correlated with the number of copulations (Table 3).

In 1990, one male $(<\mathrm{To}>)$ was always accompanied by a large number of females and participated in the largest number of aggressive encounters, having a high fighting success (Table 2 and Fig. 4). This situation seems to be more akin to a harem strategy. In 1990 the number of aggressive encounters was positively correlated with the number of females (Table 3).

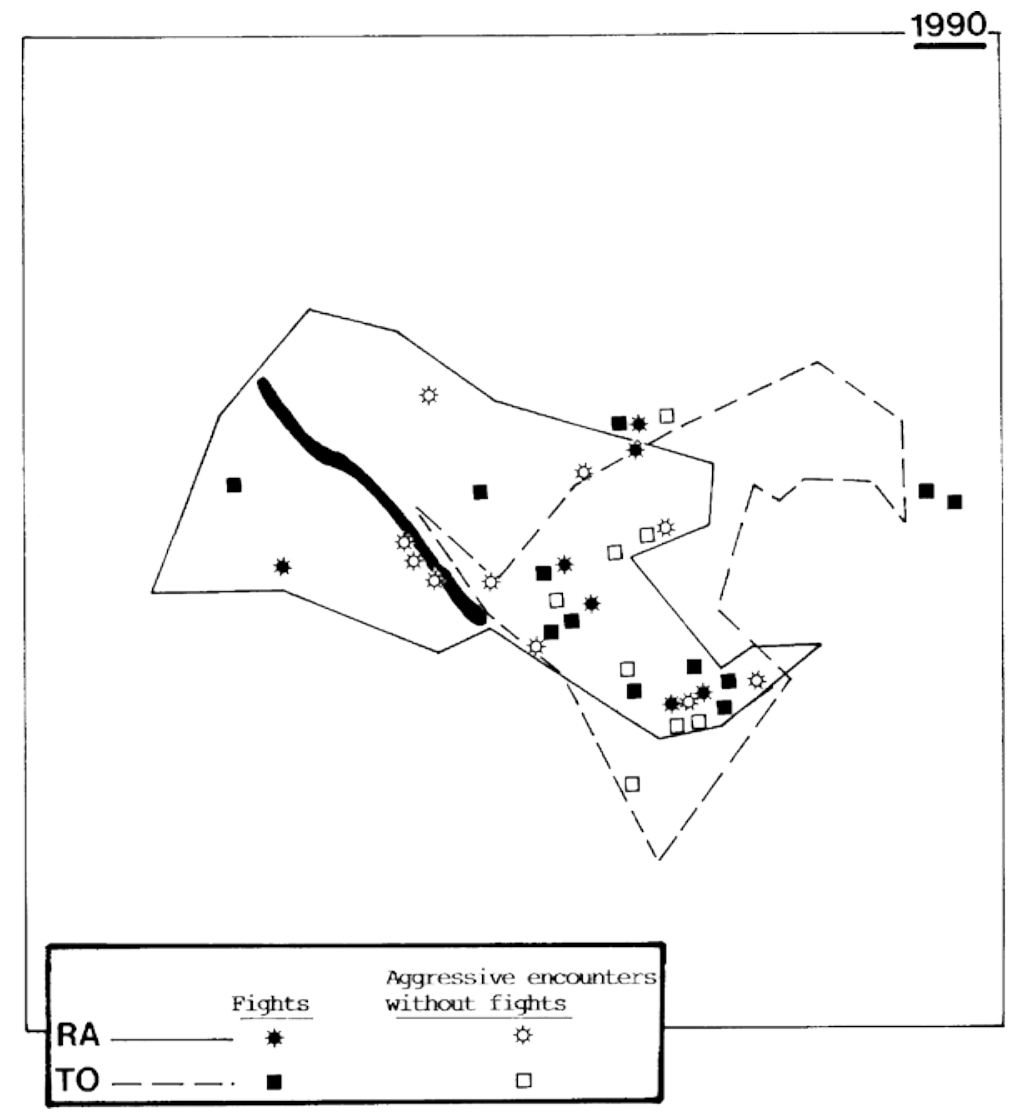

Fig. 4. - Rutting areas of males $<\mathrm{Ra}>$ and $<\mathrm{To}>$ in 1990. 


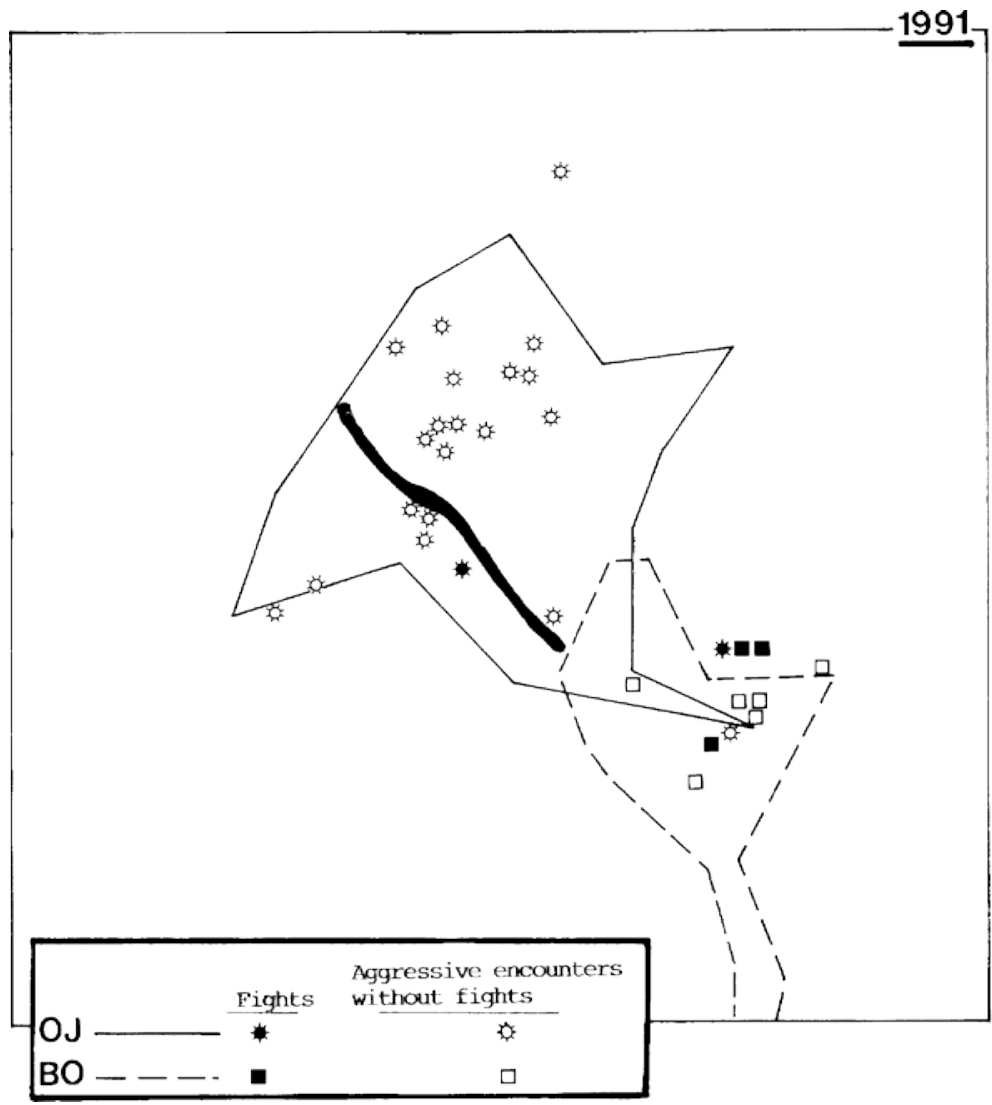

Fig. 5. - Rutting areas of males $<\mathrm{Oj}>$ and $<\mathrm{Bo}>$ in 1991.

No males seemed to follow a harem strategy in 1991 since there was no correlation between number of aggressive encounters/day and number of females (Table 3). Male $<\mathrm{Bo}>$ in 1991 (Fig. 5) - whose rutting area coincides with the area of male $<\mathrm{To}>$ in 1990 (Fig. 4) - seemed to follow a dominance-groups strategy, gaining access to a high number of females through a relatively high fighting success (Table 2).

Furthermore, in 1991 there was a relatively high number of males occupying a shared area with its centre in the rutting area of male $\langle\mathrm{Oj}\rangle$ where females were concentrated (Fig. 6). These males $(<\mathrm{Nu}\rangle\langle\mathrm{Go}\rangle\langle\mathrm{Ca}\rangle\langle\mathrm{Li}>$ ) did not shepherd females but they fought quite often (Table 2): “waiting and fighting” strategy.

In the same year (1991) another category of males could be identified: three males $(<\mathrm{Ba}><\mathrm{Fe}><\mathrm{Qu}>$ ) with low rate of aggressive encounters but associated with a relatively high number of females (Table 2), a following strategy. 


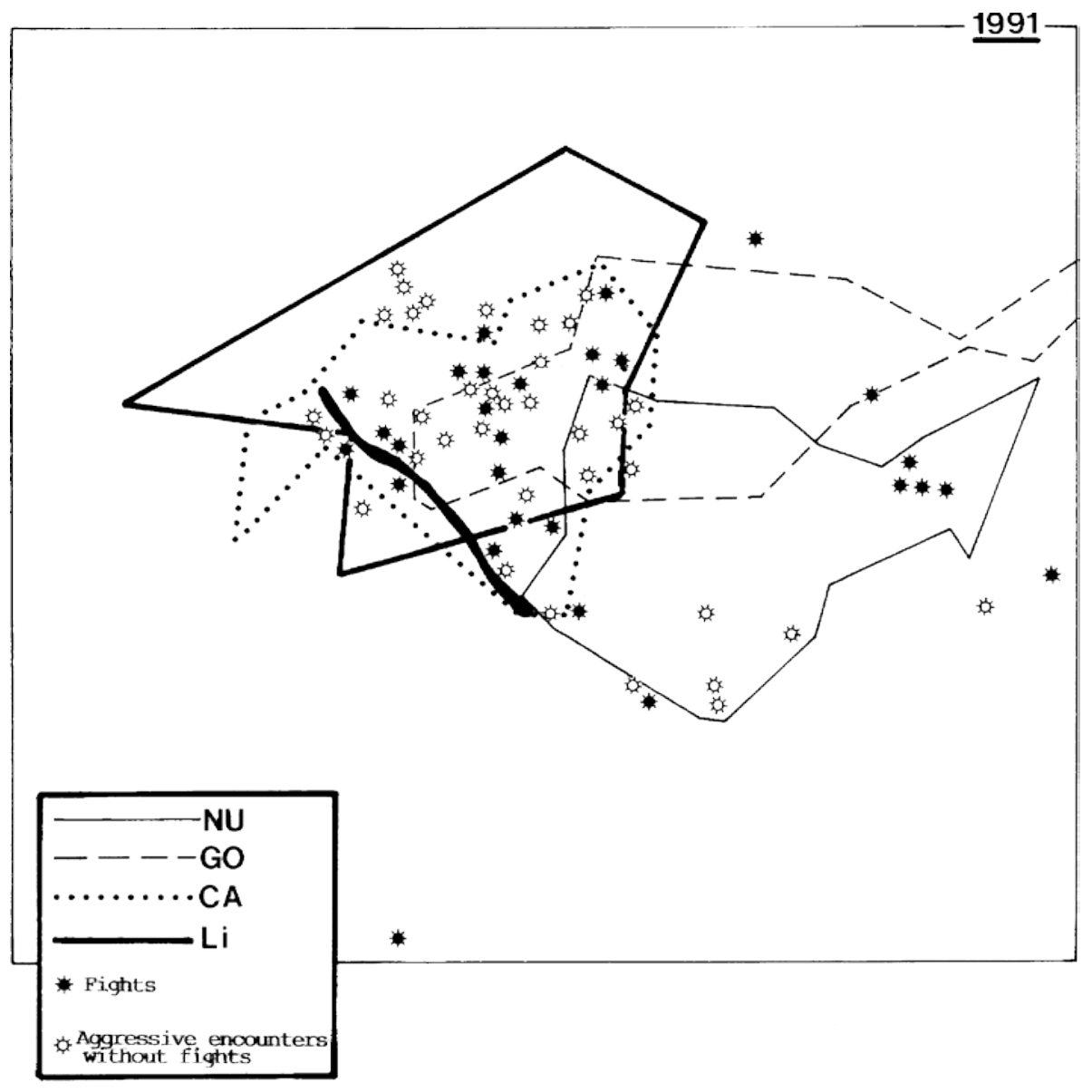

Fig. 6. - Rutting areas of males $<\mathrm{Nu}>,<\mathrm{Go}\rangle,<\mathrm{Ca}>$ and $<\mathrm{Li}>$ in 1991 .

\section{DISCUSSION}

Previous studies of Doñana fallow deer revealed mating strategies based on rutting stands (AlVAREZ et al. 1990). Regarding the data from these studies, it is interesting to note that in 1982-1983 there was only one mature male in the same "main study area" (BRAzA et al. 1986) and that in 1986 there were five adult males (Alvarez et al. 1990).

In our study, where 10-11 mature males were present in the same study area, no male had exclusive use of its rutting area. However rutting area attendance seems to be one of the most important determinants of male reproductive success, since the presence of particular bucks in the rutting area was correlated with fighting success and number of copulations. 
In both years of the study period (1990-1991) one male $(<\mathrm{Ra}>$ and $<\mathrm{Oj}>$, respectively) adopted what could be called a strategy of dominance-groups (LANGBEIN \& THIRGOOD 1989).

In 1990 a positive correlation between the number of fights and the number of females, allowed one male $(<\mathrm{To}>)$ to maintain a big harem and achieve a relatively high number of copulations. In 1991 another male $(<\mathrm{Bo}>)$ seemed to occupy the same rutting area as male $\langle\mathrm{To}\rangle$ in 1990 , but no copulations were observed there, and the number of fights was lower, as compared with other males. There was no correlation between number of fights and the number of females (harems size) that year. In our opinion, in 1991 male $<\mathrm{Bo}>$ was a male with a harem but without any success in holding a large number of females, unlike male $<\mathrm{To}>$ in 1990. This fact may have induced some females and the follower males in 1991 to move towards the rutting area of the dominant male $\langle\mathrm{Oj}\rangle$, leading to a high concentration of deer in its rutting area as shown in Fig. 3.

Population density seems to be a factor of considerable importance with regard to the great variation of mating strategies in fallow deer populations and in other ungulates (Clutton-Brock et al. 1988, 1993; Apollonio 1989; Clutton-Brock 1989; LANGBEIN \& THIRGOOD 1989; BALMFORD 1992). The significant increase in population density that occurred from 1990 to 1991 in Doñana did not seem to affect the variables related to males' reproductive success, since no significant differences were found between years neither in the number of females nor in the number of copulations. The increased density affected the size and overlap of male rutting areas but did not bring about a shift from non-territorial to territorial mating strategies.

When doe numbers become higher, and there is also an increase in the number of adult males, it is increasingly difficult for bucks to monopolize a larger number of females by use of a harem strategy. So, adopting dominance-groups remained the most successful strategy in 1991. The rest of the males adopted opportunistic strategies: some of them concentrated, waiting in areas with high concentrations of females while attempting access to them by establishing a dominance status (through fighting); the remainder became followers, trying to obtain occasional opportunities to copulate with a female in oestrus.

Thus, our hypothesis is that in Doñana during the study period, the most successful mating strategy for fallow deer was dominance-groups. That strategy was useful only for some animals; the remainder chose between other non-territorial strategies, such as harem, "waiting and fighting”, and following.

We have yet to answer the question of why lek breeding does not occur in the Doñana fallow deer population. The mating strategy traditionally described as "typical" for fallow deer - that is, "stands" - has been observed in Doñana (Alvarez et al. 1990), and harems and dominance-groups have also usually been observed in this population (BRAZA et al. 1986, present study). Population density has been increasing in the study area over the last 10 years (BRAzA et al. 1990, this study) and at present, no territorial strategies have been observed. It would appear, then, that in Doñana shifts in density do not follow the expected pattern which foresees that an increase in density contributes to continuous increases in territorial behaviour, reaching extremes such as multiple stands and lekking. Our study reveals however that increases in density favour non-territorial extremes such as dominance-groups.

It should be taken into account that when environmental conditions are unpredictable and/or the main mortality factors are predation and chaotic events, such as drought in the case of Doñana, environmental stress plays a more important role than social stress and density-dependent factors have a secondary influence on variation in mating strategies. 
The distribution and movements of females also represent determinant factors influencing the fallow deer mating system. In Doñana, females groups are stable and attached to particular areas (SAN José 1988, BRAZA et al. 1990) which could make viable the defense of harems and resources, both concentrated in the same particular areas. Dominance-groups strategy seems to be favoured when population density increases and the monopolization of females becomes difficult. In other European populations with high male density, multiple stands or lekking strategies occur where females have large ranges, do not live in stable groups and present relatively high local densities (SChaAl 1986, Clutton-Brock et al. 1988, Apollonio 1989, BALMFord 1992, Thirgood et al. 1992).

Differences in habitat structure have also been proposed as a factor influencing reproductive behaviour in fallow deer (SchaAl 1987). LANGBein \& THIRgood (1989) observed that non-territorial reproductive strategies such as harems or dominancegroups occurred only in open habitats where cohesion of females was most feasible. However, fallow deer leks have been observed in both open areas and closed woodlands (SchaAl 1986, Apollonio 1989, LANGBein \& Thirgood 1989). Probably habitat structure is an important factor to be considered, acting indirectly through its influence on female density and dispersion. The open meadows occupied by fallow deer in Doñana could favour cohesion of female groups and therefore non-territorial reproductive strategies, but could also offer suitable areas for the necessary displays of leks. In relation to this argument, it is interesting to note that our results have revealed a selective use of those meadows, where females concentrate close to the creek. At the beginning of the autumn (after the dry summer) water is a limiting resource in Doñana, that could also favour the cohesion of females.

Finally, in our opinion, in order to reach high levels of territorial behaviour in mating strategies, not only should changes in population density and/or productivity occur, but also, as was pointed out by other authors (EMLEN \& ORING 1977, LANGBEIN \& THIRGOOD 1989), a relative asynchrony of oestrus in the females is required. It has been observed that in leks, fallow deer bucks rarely hold more than nine does in their territories at a time (Clutton-Brock et al. 1988). In Doñana, where multiterritorial strategies have never been observed, a strong synchronization in births exists (BrazA et al. 1988, SAN José \& BRAZA 1992b).

We think that lek strategy could be favoured in fallow deer populations living under more stable environmental conditions than in Doñana and regulated more by density-dependent processes.

Future research on fallow deer mating systems should try to construct a model which could reveal the evolutionary equilibrium which balances survival against mating success. Mating in leks might enhance the opportunity for mate choice (CLUTTON-BROCK et al. 1988), while dominance-groups give priority to intrasexual selection. In any case, it seems difficult to collect data in natural populations to enable the documentation of the balance between natural and sexual selection and its relation to reproductive strategies.

\section{ACKNOWLEDGEMENTS}

We thank Guyonne Jans and Patricia Corrochano for their help with the field recording and data analysis. Maria Zunzunegui, from the Department of Ecology (University of Sevilla), identified the botanical specimens. We sincerely thank Enrique Collado for his help in the analysis of data and final discussion. We also thank Dr Fernando Alvarez for his comments. Alicia Prieto also made an important contribution in the preparation of the manuscript. We thank particularly Dr Tim Clutton-Brock and Dr Simon Thirgood for revising this manuscript critically. This study was supported by the Comisión Interministerial de Ciencia y Tecnología (CICYT) of Spain (project PB87-0316). 
Allier C., Gonzalez-Bernaldez F. \& Ramirez-Diaz L. 1974. Mapa Ecológico/Ecological Map. Reserva Biológica de Doñana. Sevilla: Estación Biológica de Doñana (CSIC).

Alvarez F., Braza F. \& SAn José C. 1990. Coexistence of territoriality and harem defense in a rutting fallow deer population. Journal of Mammalogy 71: 692-695.

Apollonio M. 1989. Lekking in fallow deer: just a matter of density? Ethology Ecology \& Evolution 1: 291-294.

Apollonio M., Festa-Bianchet M. \& Mari F. 1989. Correlates of copulatory success in a fallow deer lek. Behavioral Ecology and Sociobiology 25: 89-97.

BALmFord A. 1992. Social dispersion and lekking in Uganda Kob. Behaviour 120: 177-191.

Beehler B.M. \& Foster M.S. 1988. Hotshots, hotspots and female preferences in the organization of lek mating systems. American Naturalist 131: 201-219.

Beltran J.F., San José C., Delibes M. \& Braza F. 1986. An analysis of the Iberian lynx predation upon fallow deer in the Coto of Doñana, SW Spain. Proceedings XVII International Congress of Game Biologists 17: 173-181.

Bradbury J.W. 1981. The evolution of leks, pp. 138-169. In: Alexander R.D. \& Tinkle D., Edits. Natural selection and social behaviour: research and new theory. New York: Carron Press.

Braza F. 1975. Censo del gamo (Dama dama) en Doñana. Naturalia Hispanica 3: 1-27.

Braza F. \& Alvarez F. 1987. Habitat use by red deer and fallow deer in Doñana National Park. Miscel.lania Zoologica 11: 363-367.

Braza F., Alvarez F., Geldof R. \& Byloo H. 1984. Desplazamientos de ungulados silvestres a través de una zona de ecotono en Doñana. Doñana, Acta Vertebrata 11: 275-287.

Braza F., Garcia J.E. \& Alvarez F. 1986. Rutting behaviour of fallow deer. Acta Theriologica 31: 467-478.

Braza F., San José C. \& Blom A. 1988. Birth measurements, parturition dates and progeny sex ratio of Dama dama in Doñana, Spain. Journal of Mammalogy 69: 607-610.

Braza F., San José C., Blom A., Cases V. \& Garcia J.E. 1990. Population parameters of fallow deer at Doñana National Park (SW Spain). Acta Theriologica 35: 277-288.

Castroviejo J. 1993. Mapa del Parque Nacional de Doñana. Sevilla: Consejo Superior de Investigaciones Científicas/Junta de Andalucía.

Clutton-Brock T.H. 1989. Mammalian mating systems. Proceedings of the Royal Society of London 236: 339-372.

Clutton-Brock T.H., Albon S.D., Gibson R.M. \& Guinness F.E. 1979. The logical stag: adaptive aspects of fighting in red deer (Cervus elaphus L.). Animal Behaviour 27: 211-225.

Clutton-Brock T.H., Deutsch J. \& Nedft R.J. 1993. The evolution of ungulate leks. Animal Behaviour 46: 1121-1138.

Clutton-Brock T.H., Green D., Hiraiwa-Hasegawa M. \& Albon S.D. 1988. Passing the buck: resource defence, lek breeding and mate choice in fallow deer. Behavioral Ecology and Sociobiology 23: 281-296.

EMLEN S.T. \& ORING L.W. 1977. Ecology, sexual selection, and the evolution of mating systems. Science 197: 215-223.

Harvey M.J. \& BARbour R.W. 1965. Home range of Microtus ochrogaster as determined by a modified minimum area method. Journal of Mammalogy 46: 398-402.

KENWARD R. 1987. Wildlife radio tagging. Equipment, field techniques and data analysis. London: Academic Press. 
LANGBEIN J. \& ThiRgood S.J. 1989. Variation in mating system of fallow deer (Dama dama) in relation to ecology. Ethology 83: 195-214.

LUDWING J.A. \& REYNOLDS J.F. 1988. Statistical ecology: a primer on methods and computing. New York: John Wiley and Sons.

Moore N.P., Kelly P.F., CAhill J.P. \& Hayden T.J. 1995. Mating strategies and mating success at fallow bucks in a non-lekking population. Behavioral Ecology and Sociobiology 36: 91-100.

Ojeda J., Braza F., Alvarez F. \& Azcarate T. 1983. La población de gamos del Parque Nacional de Doñana en 1979. Doñana, Acta Vertebrata 10: 221-224.

Queller D.C. 1987. The evolution of leks through female choice. Animal Behaviour 35: 14241432.

SAN José C. 1988. Estrategia reproductiva de las hembras de gamo (Dama dama). Tesis Doctoral, Madrid: Universidad Complutense de Madrid.

SAN José C. \& BrAZA F. 1992a. An approach to management of wild populations of fallow deer (Dama dama) in Doñana National Park, pp. 229-232. In: Bobek B. et al., Edits. Global trends in wildlife management. Krakovia: Swiat Press.

SAN José C. \& BRAZA F. 1992b. Antipredator aspects of fallow deer behaviour during calving season at Doñana National Park (Spain). Ethology Ecology \& Evolution 2: 139-149.

SCHAAL A. 1985a. Variation of mating system in fallow deer (Dama dama). Abstracts 19th Ethological Congress, Toulouse 1: 227.

SchaAl A. 1985b. Observations préliminaires sur le cycle sexuel du daim, Cervus (dama) dama. Mammalia 49: 288-291.

SchaAl A. 1986. Mise en évidence d'un comportement de reproduction en arène chez le daim d'Europe (Dama d. dama). Compte Rendu de l'Académie des Sciences, Paris (III) 303 (18): 729-732.

SchaAl A. 1987. Le polymorphism du comportement reproducteur chez le daim d'Europe, Dama dama. Contribution à la social-écologie des Cervidae. Ph.D. Thesis, Strasbourg: University Louis-Pasteur.

SIEgel S. 1956. Nonparametric statistics for the behavioral sciences. New York: MacGraw-Hill Book Co.

SNELl E.J. 1987. Applied statistics: a handbook of BMDP analyses. London, New York: Chapman \& Hall.

StÈrba O. \& KlusÁK K. 1984. Reproductive biology of fallow deer, Dama dama. Acta Scientiarum Naturalium Brno 18: 1-46.

THIRGOOD S.J. 1990. Alternative mating strategies and reproductive success in fallow deer. Behaviour 116: 1-10.

Thirgood S.J., Robertson A., Jarvis A.H., Belbin S.V., Robertson D. \& Nefdt R.J. 1992. Mating system and ecology of black lechwe (Kobus: Bovidae) in Zambia. Journal of Zoology, London 228: 155-172. 